\title{
RANCANG BANGUN SISTEM INFORMASI PROFIL UKM PENGOLAHAN HASIL PERTANIAN SAMBAS BERBASIS ANDROID
}

\author{
Heldi Hastriyandi ${ }^{1)}$, Junardi ${ }^{2)}$ \\ ${ }^{1}$ Manajemen Informatika, ${ }^{2}$ Agrobisnis \\ Politeknik Negeri Sambas \\ E-mail: heldi.poltesa@gmail.com
}

\begin{abstract}
Abstrak - Usaha Kecil dan Menengah (UKM) memiliki andil yang sangat strategis dalam memajukan perekonomian di Indonesia.Oleh karena itu pelaku UKM perlu mendapatkan perhatian yang besar untuk dapat mengembangkan usahanya. Faktor-faktor yang menjadi kendala adalah minimnya pemasaran hasil produk, pengembangan aneka produk yang belum memadai, serta kurangnya permodalan.Untuk mengatasinya diperlukan langkah-langkah yang strategis dalam mengembangkan UKM industri pengolahan hasil pertanian khususnya sektor pangan, perkebunan dan hortikultura. Salah satunya melalui penyediaan informasi berupa profil, jenis produk maupun sebarannya. Dengan harapan masyarakat luas dapat mengetahui dan mengakses informasi profil dan sebaran UKM dengan mudah serta dapat menarik minat investor. Untuk kemudahan akses tersebut maka diperlukan sebuah aplikasi dengan mengkombinasikan mobile internet dan GPS pada perangkat smartphone android untuk memberikan informasi lokasi dengan tampilan berupa Maps memamfaatkan teknologi google map platform. Metode yang dilakukan dalam penelitian ini yaitu pengumpulan data berupa data spasial (survey titik koordinat) serta data non spasial berupa data UKM serta data atributnya, Tahapan selanjutnya berupa desain aplikasi tampilan user interface berbasis android dan pembuatan database dengan menggunakan layanan google fusion. Tahapan akhir penelitian berupa validasi pengujian program dengan menggunakan metode blackbox. Pada penelitian ini akan dihasilkan sebuah aplikasi sistem informasi produk dan sebaran UKM pengolahan hasil pertanian Kabupaten Sambas berbasis Android.
\end{abstract}

Kata Kunci: Android Smartphone, Sistem Informasi, Profil UKM, Pertanian, Kabupaten Sambas

\section{PENDAHULUAN}

Dalam membangun perekonomian, usaha kecil dan menengah (UKM) memiliki andil yang sangat signifikan.UKM mempunyai kedudukan yang sangat strategis dalam memajukan perekonomian di Indonesia.UKM sebagai kekuatan ekonomi nasional tidak banyak terpengaruh pada krisis ekonomi yang terjadi, oleh karena itu kelompok pelaku UKM perlu mendapatkan perhatian yang besar. Pengembangan UKM di Kabupaten Sambas saat ini masih sangat minim. Dari segi jumlah pelaku UKM di kabupaten Sambas sudah cukup banyak namun hingga saat ini belum dapat mengembangkan usahanya (Bappeda Kab.Sambas,2016). Hal ini disebabkan oleh beberapa faktor diantaranya minimnya pemasaran hasil produk, pengembangan aneka produk yang belum memadai, serta kurangnya permodalan. Untuk mengatasi hal tersebut diperlukan langkahlangkah yang strategis dalam mengembangkan dan meningkatkan UKM yang ada di kabupaten Sambas, salah satunya melalui penyediaan informasi baik berupa jenis-jenis produk yang dihasilkan oleh UKM serta sebaran lokasi/wilayah UKM. Dengan adanya media penyampaian informasi ini diharapkan masyarakat luas dapat mengetahui produk UKM dan sebarannya di kabupaten Sambas serta dapat mengakses informasi tersebut dengan mudah, bahkan dapat menarik minat investor sehingga dapat meningkatkan permodalan bagi pelaku UKM itu sendiri.

Dengan perkembangan teknologi smartphone dan sistem operasi yang bersifat open source serta perkembangan perangkat lunak berupa pemetaan wilayah (mapping), hal ini sangat mungkin untuk dilakukan sebagai upaya dalam mendukung pengembangan dan peningkatan UKM salah satunya melalui rancang bangun aplikasi perangkat lunak berbasis android yang dapat memberikan informasi sebaran lokasi/wilayah UKM yang terdapat di kabupaten Sambas serta jenis - jenis produk yang dihasilkannya. Dengan adanya sistem informasi sebaran dan produk UKM pada perangkat smartphone, tentu hal ini akan mempermudah masyarakatdalam mengakses berbagai informasi yang dibutuhkan diantaranya produk yang dijual, profil UKM, bahkan masyarakat dapat mengetahui lokasi UKM tersebut melalui peta dengan menggunakan Google Maps Api. Berdasarkan uraian diatas, maka rumusan masalah adalah sebagai berikut bagaimana merancang sebuah aplikasi mobile sebagai media yang dapat mempermudah masyarakat dan investor dalam mendapatkan informasi mengenai hasil produk dan lokasi UKM yang tersebar di kabupaten 
Sambas serta bagaimana mengkombinasikan mobile internet dan GPS pada perangkat smartphone android dalam memberikan informasi sebaran lokasi UKM dengan teknologi Google Maps. Tujuan dari penelitian ini adalah untuk menyajikan informasi mengenai profil dan persebaran UKM pengolahan hasil pertanian yang terdapat di kabupaten Sambas dengan menggunakan sistem informasi berbasis android, sehingga mudah diakses oleh masyarakat terutama dikabupaten Sambas.

\section{METODE PENELITIAN}

Penelitian ini dilakukan dengan beberapa tahapan pelaksanaan terutama agar dalam pengolahan datanya dapat mencapai hasil yang diharapkan. Adapun tahapan tersebut dapat dilihat pada gambar 1.

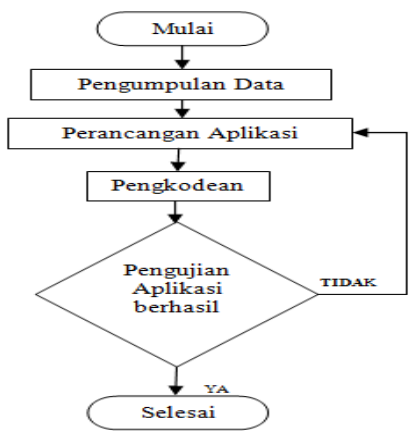

Gambar 1. Metode Penelitian

Adapun rincian tahapan pelaksanaan penelitian dapat dijelaskan sebagai berikut :

1. Tahapan Pengumpulan Data

a. Tahapan pengumpulan data diawali dengan mencari data mengenai penelitian (literatur review) yang berkaitan maupun sebagai referensi bagi peneliti dalam membangun sistem yang akan dibuat. Adapun beberapa penelitian tersebut sebagai berikut :

Ninjing Ma (2012) dalam penelitiannya, menitikberatkan pada penggunaan google map dalam menampilkan visualisasi penyampaian informasi berita yang selama ini masih dilakukan secara konvensional berupa teks, dimana penonton (audience) lebih banyak memberikan perhatian pada gambar dibanding teks. Penggunaan Google Map dalam penelitian ini mmberikan kemudahan pada audience berupa property antara lain lokasi, waktu, tampilan karakter/simbol. Penelitian ini juga membuat sebuah antarmuka (interface) dengan menggunakan google map yang dipadukan dengan beberapa bahasa pemrograman lainnya. Metode yang digunakan dalam penelitian ini berupa segmentasi teks berita, pemilihan waktu serta lokasi. Selain itu juga dilakukan pengambilan titik koordinat longitude dan latitude dari lokasi berita, kemudian data tersebut disimpan dalam database. Adapun tabel database yang dibuat sebanyak 2 tabel terdiri dari tabel berita dan tabel nama kota. Untuk tabel berita terdiri dari field berupa judul, URL, konten, lokasi, longitude, latitude, waktu. Pada desain tampilan visual digunakan kontrol pada map berupa skala serta teknik zoom. Penelitian ini telah berhasil menerapkan visualisasi pada penyampaian informasi berita dengan menggunakan google map berupa pemetaan lokasi sehingga memudahkan audience memperoleh informasi secara efektif.

Dalam penelitian B. R. Rompas (2012) berupaya membuat aplikasi berbasis android untuk melakukan pencarian tempat berdasarkan lokasi (LBS) di kota Manado. Sistem yang dibuat memanfaatkan teknologi GPS dalam pengaplikasiannya. Selain dapat mengetahui posisi pengguna, aplikasi LBS juga dapat menentukan posisi tempat-tempat tertentu. Dan dengan kombinasi ini, aplikasi LBS akan mencari rute untuk menghubungkan posisi pengguna dengan suatu tempat. Adapun metode yang digunakan dalam penelitian ini berupa pengumpulan studi literatur, penggunaan software pendukung, perancangan database, serta perancangan struktur program. Penelitian ini menghasilkan aplikasi untuk mencari tempat secara akurat sesuai hardware gps smartphone yang digunakan.

Dalam penelitian Febrian Wahyutama (2013) membahas pembuatan sarana penyampaian informasi spesifikasi dan harga barang yang interaktif pada teknologi mobile khususnya Android. Penggabungan teknologi Augmented Reality dengan Barcode pada teknologi mobile diharapkan akan membantu konsumen dalam mendapatkan informasi yang lebih ketika memilih barang yang akan dibeli dan membandingkannya dengan barang lain pada toko elektronik sehingga konsumen tidak salah dalam membeli barang yang dibutuhkan. Adapun metode yang digunakan dalam penelitian ini dimulai dengan menganalisa kebutuhan kebutuhan yang terdiri atas kebutuhan fungsional dan kebutuhan user sistem. Penelitian ini menghasilkan aplikasi Sarana Penyampaian Informasi Spesifikasi dan Harga Barang yang Interaktif Berbasis Android.

Penelitian yang dilakukan oleh Adhika Novandya (2012) membahas mengenai sebuah aplikasi yang menampilkan informasi mengenai kebudayaan yang ada pada setiap provinsi di Indonesia. Penelitian ini bertujuan agar dapat membantu masyarakat dalam mendapatkan pengenalan dan pengetahuan mengenai berbagai macam keanekaragaman budaya yang ada di Indonesia. Metode yang digunakan berupa studi pustaka, dilanjutkan dengan tahapan pembuatan struktur aplikasi, tahapan akhir berupa implementasi dengan menggunakan bahasa pemrograman Java dan XML.

b. Tahapan Pengumpulan data non spasial 
Dalam tahapan ini, penulis mencari informasi mengenai data jenis usaha UKM yang bergerak pada bidang pengolahan hasil pertanian yang terdapat di kabupaten Sambas yaitu berupa jumlah, profil UKM, serta alamat UKM tersebut melalui dinas terkait. Adapun format penyajian data profil UKM dapat dilihat pada tabel 1.

Tabel 1 Format Penyajian data Profil dan Sebaran UKM

\begin{tabular}{|c|c|c|c|c|c|c|}
\hline No & $\begin{array}{c}\text { Nama } \\
\text { Pemilik Usaha }\end{array}$ & Alamat & Kecamatan & $\begin{array}{c}\text { Jenis } \\
\text { Usaha }\end{array}$ & $\begin{array}{l}\text { Lama } \\
\text { Usaha }\end{array}$ & $\begin{array}{l}\text { Bahan } \\
\text { Baku }\end{array}$ \\
\hline
\end{tabular}

c. Tahapan Pengumpulan Data Spasial

Setelah didapatkan informasi mengenai data profil UKM tersebut, maka langkah selanjutnya adalah mengumpulkan sebaran UKM dengan cara melaksanakan survey lokasi untuk pengambilan titik koordinat dengan menggunakan GPS serta melakukan dokumentasi terhadap produk UKM. Adapun format tabel Sebaran titik koordinat UKM dapat dilihat pada tabel 2 .

Tabel 2 Format Penyajian Titik Koordinat Sebaran UKM

\begin{tabular}{|c|c|c|c|c|c|}
\hline No & $\begin{array}{c}\text { Nama } \\
\text { Pemilik Usaha }\end{array}$ & Alamat & Kecamatan & $\begin{array}{c}\text { Titik } \\
\text { Koordinat }\end{array}$ & $\begin{array}{c}\text { Foto } \\
\text { Produk (Link) }\end{array}$ \\
\hline
\end{tabular}

\section{Perancangan Aplikasi}

Pada tahapan ini dirancang dan dibuat tampilan user interface serta membuat database dengan menggunakan google fusion table. Tahapan ini dimulai dengan desain tampilan serta pengkodean. Untuk memudahkan user dalam menggunakan sebuah aplikasi diperlukan perancangan interface baik dari segi tampilan maupun fungsional. Adapun desain tampilan user interface pada penelitian ini terdiri atas :

a. Rancangan Halaman Splash Menu Utama dan Menu Pencarian Data

Halaman splash berfungsi sebagai tampilan awal aplikasi yang berupa icon dan informasi mengenai versi aplikasi agar memudahkan pengembangan aplikasi. Pada Rancangan halaman splash juga terdapat tombol untuk masuk ke menu berikutnya dan tombol keluar aplikasi. Pada aplikasi terdapat menu utama yang berfungsi sebagai antarmuka aplikasi sehingga user dapat melihat baik berupa profil UKM maupun tampilan sebaran UKM dalam bentuk peta menggunakan google map API. Pada menu utama user juga terdapat menu pencarian sehingga user dapat memilih profil UKM berdasarkan kecamatan dan id pemilik UKM. Adapun rancangan tampilan halaman splash, menu utama, dan menu pencarian dapat dilihat pada gambar 2 - 4 .

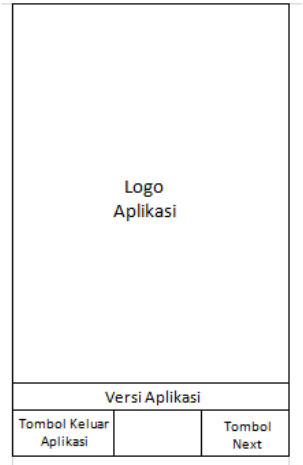

Gambar 2. Rancangan Halaman Splash

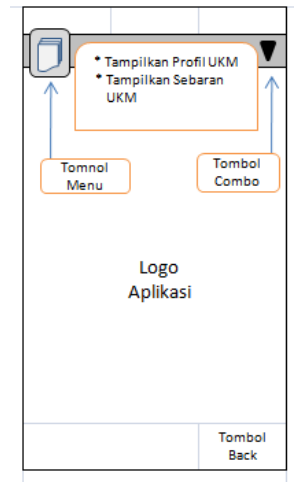

Gambar 3. Rancangan Halaman Menu Utama

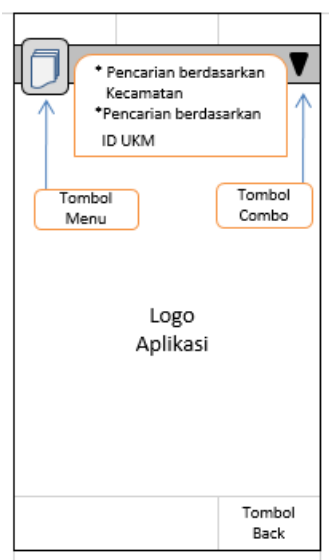

Gambar 4. Rancangan Halaman Pencarian Data 
b. Rancangan Halaman Profil UKM dan Sebaran UKM

Halaman Profil UKM merupakan halaman untuk menampilkan Profil UKM dalam bentuk tabel. Untuk menampilkan halaman ini, peneliti menggunakan kode Cascade Style Sheet (CSS), hal ini untuk mempermudah pengaturan tampilan Foto Produk UKM serta Deskripsi Profil UKM sehingga dapat tertata dengan baik. Adapun layout pengaturan dan penempatan foto produk dan deskripsi profil UKM pada tampilan halaman ini dapat dilihat pada gambar 5. Selain untuk tampilan profil UKM, pada bagian ini peneliti juga merancang halaman untuk menampilkan sebaran UKM dalam bentuk tampilan peta yang nantinya terkoneksi langsung dengan google map APIs. Untuk dapat menampilkan sebaran UKM dalam bentuk peta (map), perlu dilakukan penyesuaian ukuran baik tinggi maupun lebar map. Adapun rancangan tampilan halaman sebaran UKM menggunakan google map APIs dapat dilihat pada gambar 6 .

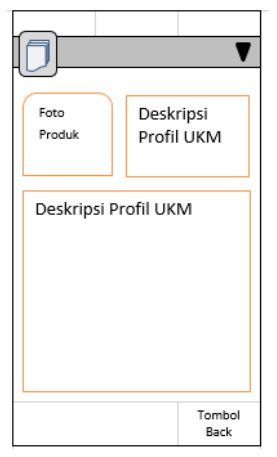

Gambar 5. Tampilan Rancangan Profil UKM

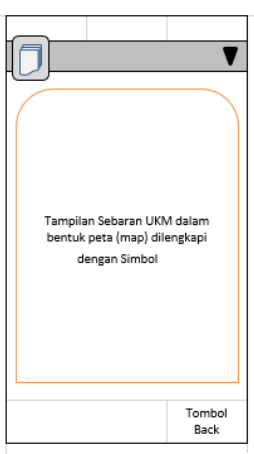

Gambar 6. Tampilan Rancangan Halaman Sebaran UKM
Pada tahapan ini juga dirancang database dan tabel sehingga memudahkan penyimpanan dan pemanggilan data. Rancangan database menggunakan google fusion table karena telah dilengkapi dengan fitur tampilan peta dengan menginputkan data titik koordinat berupa typedata : location (latitude dan longitude). Adapun rancangan database Profil dan sebaran data UKM dapat dilihat pada tabel 3.

Setelah dirancang field data dan tipe data yang bersesuaian, maka langkah selanjutnya adalah membuat dan menerapkan field data tersebut menggunakan Fusion Table. Adapun rancangan Database Menggunakan Fusion Table pada tahapan ini dapat dilihat pada gambar 7 .
Tabel 3 Rancangan Database Tabel Profil dan Sebaran data UKM

\begin{tabular}{cccc}
\hline No & Nama Field & $\begin{array}{c}\text { Type } \\
\text { Data }\end{array}$ & Format \\
\hline 1 & No & Text & None \\
\hline 2 & $\begin{array}{c}\text { Nama Pemilik } \\
\text { Usaha }\end{array}$ & Text & None \\
\hline 3 & Foto UKM & Text & $\begin{array}{c}\text { Single Line } \\
\text { Image }\end{array}$ \\
\hline 4 & Alamat & Text & None \\
\hline 5 & Kecamatan & Text & None \\
\hline 6 & Lokasi & Location & $\begin{array}{c}\text { Latitude } \\
\text { Longitude }\end{array}$ \\
\hline
\end{tabular}

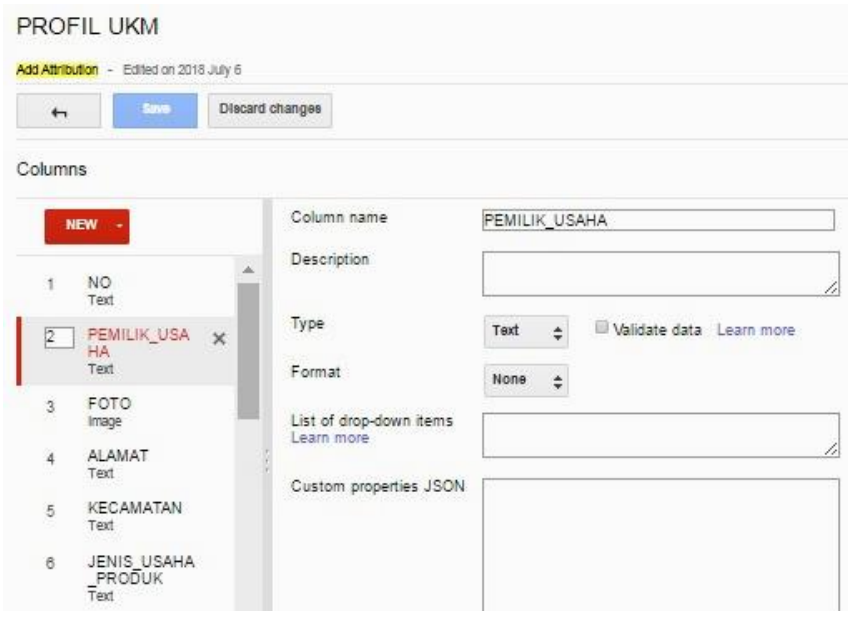

Gambar 7. Tampilan Rancangan Database Menggunakan Fusion Table

\section{HASIL DAN PEMBAHASAN}

Dari hasil proses penelitian ini diperoleh sebuah aplikasi sistem informasi profil dan sebaran UKM pengolahan hasil pertanian di Kabupaten Sambas berbasis Android. Adapun hasil penelitian ini sebagai berikut :

a. Tampilan Halaman Splash Menu Utama dan menu Pencarian data

Setelah menjalankan file ProfilUKM_Sambas.apk, akan muncul halaman splash dimana tampilan ini merupakan tampilan awal aplikasi untuk memberikan informasi kepada user mengenai versi aplikasi dan menyediakan tombol next yang berfungsi untuk masuk ke halaman menu utama 
aplikasi. Adapun tampilan halaman splash dan halaman menu utama dapat dilihat pada gambar 89. Selain itu pada aplikasi terdapat menu pencarian berdasarkan Kecamatan maupun id pemilik UKM. Tampilan halaman menu pencarian dapat dilihat pada gambar 10 .

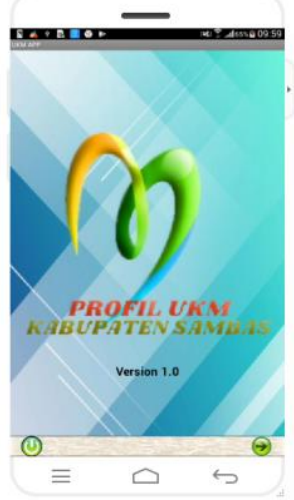

Gambar 8. Tampilan Halaman Splash

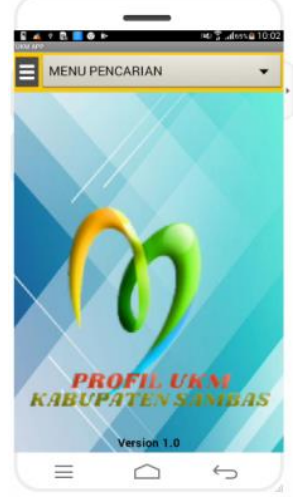

Gambar 9. Tampilan Halaman Menu Utama

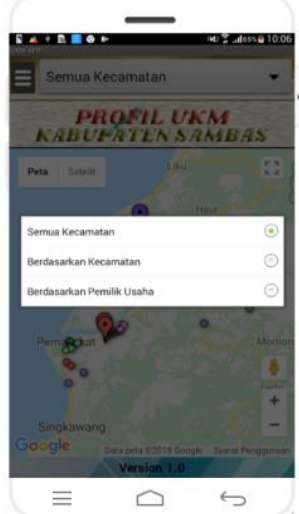

Gambar 10. Tampilan

Halaman Pencarian Data

b. Tampilan Halaman Profil UKM dan Sebaran UKM

Halaman profil dan sebaran UKM merupakan halaman yang menampilkan deskripsi profil UKM dalam bentuk tabel. Data UKM yang disajikan terkoneksi langsung dengan database yang dibuat menggunakan google fusion table. Adapun tampilan halaman Profil UKM dapat dilihat pada gambar 11. Halaman tampilan sebaran UKM merupakan halaman yang berfungsi untuk menampilkan data Lokasi UKM dalam bentuk peta yang terkoneksi langsung dengan google map, sehingga user dapat melihat lokasi dan kecamatan dari UKM tersebut. Adapun tampilan halaman sebaran
UKM dapat dilihat pada gambar 12. Pada halaman sebaran UKM, user juga dapat melihat deskripsi UKM dengan mengklik icon simbol yang terdapat pada setiap data UKM. Adapun tampilkan deskripsi UKM ini dapat dilihat pada gambar 13 .
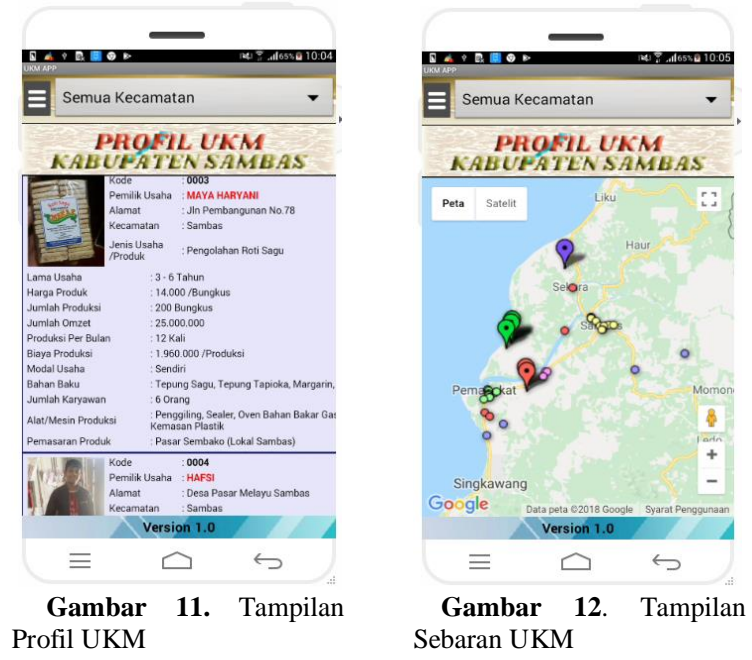

Gambar 12. Tampilan Sebaran UKM

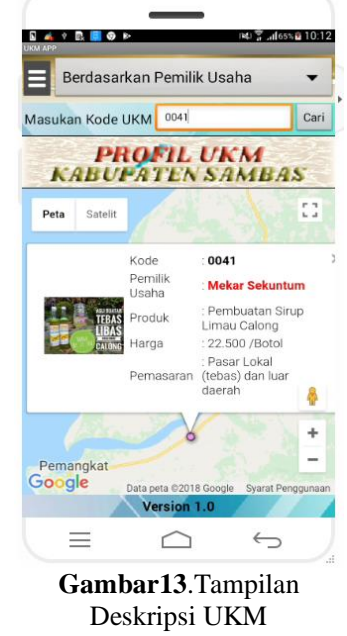

c. Uji Validasi

Setelah aplikasi berhasil dibuat maka tahapan selanjutnya adalah melakukan pengujian untuk memvalidasi aplikasi. Tahapan pengujian dilakukan dengan metode blackbox, dimana dalam metode ini disajikan dalam bentuk tabel untuk mengetahui hasil pengujian apakah sudah sesuai dengan hasil yang diharapkan terkait skenario yang dibuat.Adapun pengujian pada sistem dapat dilihat pada tabel 4. 
Tabel 4 Tabel Pengujian Sistem

\begin{tabular}{|c|c|c|c|}
\hline No & Pengujian & Skenario Pengujian & Keterangan \\
\hline 1 & $\begin{array}{l}\text { Pengujian pada } \\
\text { Halaman Splash }\end{array}$ & $\begin{array}{l}\text { Pada saat aplikasi dijalankan pertama kali maka sistem } \\
\text { akan menampilkan icon aplikasi serta terdapat tombol } \\
\text { keluar dan tombot Next, jika tombol keluar di klik maka } \\
\text { system akan menutup aplikasi dan jika tombol next di klik } \\
\text { maka sistem akan menampilkan menu Utama }\end{array}$ & Berhasil \\
\hline 2 & $\begin{array}{l}\text { Pengujian pada } \\
\text { Halaman Menu } \\
\text { Utama }\end{array}$ & $\begin{array}{l}\text { Pada Form ini sistem akan menampilkan pilihan berupa } \\
\text { tampilkan berdasarkan Profil UKM, tampilkan berdasarkan } \\
\text { Sebaran UKM, dan tampilan Informasi mengenai } \\
\text { programmer/peneliti }\end{array}$ & Berhasil \\
\hline 3 & $\begin{array}{l}\text { Pengujian pada } \\
\text { Halaman Tampilan } \\
\text { berdasarkan Profil } \\
\text { UKM }\end{array}$ & $\begin{array}{l}\text { Dengan memilih menu tampilkan berdasarkan profil UKM, } \\
\text { maka sistem akan menampilkan Foto Profil UKM dan } \\
\text { deskripsi UKM menggunakan format tabel }\end{array}$ & Berhasil \\
\hline 4 & $\begin{array}{l}\text { Pengujian pada } \\
\text { Halamam Tampilan } \\
\text { Sebaran UKM }\end{array}$ & $\begin{array}{l}\text { Dengan memilih menu tampilkan sebaran UKM, maka } \\
\text { sistem akan menampilkan sebaran data UKM dalam bentuk } \\
\text { map yang dilengkapi dengan simbol untuk menandai } \\
\text { masing-masing kecamatan yang terkoneksi dengan google } \\
\text { map }\end{array}$ & Berhasil \\
\hline 5 & $\begin{array}{l}\text { Pengujian Halaman } \\
\text { Pencarian Data }\end{array}$ & $\begin{array}{l}\text { User dapat melakukan pencarian data UKM baik } \\
\text { berdasarkan kecamatan maupun berdasarkan id pemilik } \\
\text { UKM }\end{array}$ & Berhasil \\
\hline 6 & $\begin{array}{l}\text { Pengujian tampilan } \\
\text { Deskripsi Profil } \\
\text { UKM pada halaman } \\
\text { Sebaran UKM }\end{array}$ & $\begin{array}{l}\text { User dapat melihat deskripsi UKM dengan mengklik icon } \\
\text { pada masing - masing UKM dan sistem dapat } \\
\text { menampilkan data tersebut sesuai dengan yang terdapat } \\
\text { pada database }\end{array}$ & Berhasil \\
\hline
\end{tabular}

\section{SIMPULAN}

Berdasarkan implementasi dan uji coba aplikasi yang dibangun, penulis dapat menarik beberapa kesimpulan, yaitu:

1. Penelitian ini telah berhasil membangun sebuah aplikasi untuk memberikan informasi baik berupa profil UKM maupun sebaran UKM pengolahan hasil pertanian yang terdapat di kabupaten Sambas.

2. Aplikasi yang dihasilkan telah terdapat menu pencarian sehingga user dapat dengan mudah melakukan pencarian data UKM berdasarkan kecamatan dan id pemilik UKM.

3. Aplikasi dapat menampilkan data deskripsi dan sebaran UKM dengan terkoneksi langsung pada Google Map, sehingga memudahkan user memperoleh lokasi usaha UKM tersebut dalam bentuk tampilan peta lokasi.

Adapun saran yang dapat penulis sampaikan dalam penelitian ini yaitu :

Untuk meningkatkan fungsional sistem yang dibuat, sebaiknya aplikasi tingkatkan dengan menyediakan fitur berupa grafik. Peningkatan fitur ini dimaksudkan agar memudahkan pihak-pihak yang berkepentingan.

\section{REFERENSI}

[1] Adhika Novandya,dkk. Aplikasi Pengenalan Budaya Dari 33 Provinsi Di Indonesia Berbasis Android. Prosiding : Seminar Ilmiah Nasional Komputer Dan Sistem Intelijen (Kommit 2012). Universitas Gunadarma

[2] Badan Perencanaan Pembangunan Daerah (Bappeda) Kabupaten Sambas. 2016. Profil Kabupaten Sambas

[3] B. R. Rompas. "Aplikasi Location-Based Service Pencarian Tempat Di Kota Manado Berbasis Android“. Jurnal Teknik Elektro Dan Komputer Unsrat Vol 1, No 2 (2012): Jurnal Teknik Elektro Dan Komputer.

[4] Febrian Wahyutama,dkk. Penggunaan Teknologi Augmented Reality Berbasis Barcode sebagai Sarana Penyampaian Informasi Spesifikasi dan Harga Barang yang Interaktif Berbasis Android, Studi Kasus pada Toko Elektronik ABC Surabaya. Jurnal Teknik Pomits Vol. 2, No. 3, (2013)

[5] Heri Tristiantoro, Teguh Sutanto, M.Kom.,MCP dan Erwin Sutomo, S.Kom, 2012. Aplikasi Panduan Wisata Belanja Menggunakan Indoor Maps Berbasis Android Di Surabaya ( Studi Kasus : Dinas Kebudayaan Dan Pariwisata Surabaya).Jurnal JSIKA Vol 1, No 1 
JUST TI, Volume 11 Nomor 1, Januari 2019: 24-30

[6] Hubeis, M. 2006. Pengantar Industri Kecil Menengah. Modul Kuliah, Program Magister Profesional Industri Kecil Menengah, Sekolah pascasarjan, Institut Pertanian Bogor. Bogor.

[7] Hubeis, M. 2009. Prospek Usaha Kecil Menengah dalam Wadah Inkubstor Bisnis, Ghalia Indonesia, Jakarta.

[8]Konsep Dasar Sistem Informasi, http://www.unsri.ac.id/upload/arsip/BAB\%20I.pdf [27 Maret 2017]

[9] Nazruddin Safaat H. 2011. Pemrograman Aplikasi Mobile Smartphone dan Tablet PC berbasis Android. Informatika, Bandung

[10] Ningjing Ma. Mapping News : The service of complementing information visualization based on interface of Google Map, Software Engineering and Service Science (ICSESS), IEEE 3rd International Conference

on, DOI: 10.1109/ICSESS.2012.6269454, 2012.

[11] Saifulrahman, 2010.Pengantar Sistem Informasi. http://saifulrahman.lecture.ub.ac.id/files/2010/03/Pen gantar-SistemInformasi.pdf [27 Maret 2017] 